\title{
Interview on Marxism, Critical Pedagogy and Inclusive Education: Discussions for a Revolutionary Discourse
}

\author{
Glenn Rikowski interviewed by Aldo Ocampo González**
}

Dr. Glenn Rikowski is a Visiting Fellow in the College of Social Science, University of Lincoln, UK. From March 2014 - March 2015, he was a Visiting Scholar in the Department of Education at Anglia Ruskin University, Chelmsford. Up to 31 ${ }^{\text {st }}$ October 2013, Rikowski was a Senior Lecturer in Education Studies in the School of Education at the University of

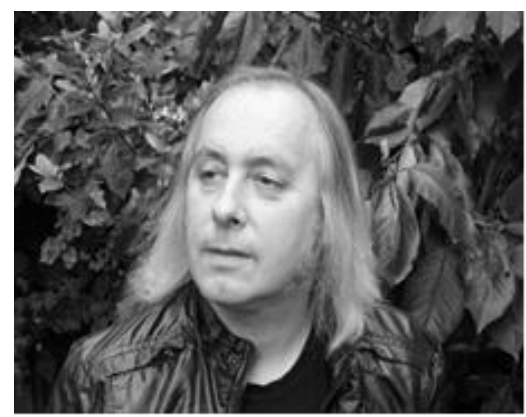
Northampton. He was previous a supply teacher in East London (2001), a Senior Research Fellow in Lifelong Learning at the University of Central England (1999-2001) and a Research Fellow in the School of Education, University of Birmingham (1994-1999). Prior to that, Glenn taught in further education colleges and secondary schools in Essex and London (1985-1989) and at Epping Forest College (19891994). His publications include: The Battle in Seattle: Its Significance for Education (2001, Tufnell Press), and (with Dave Hill, Peter McLaren and Mike Cole) the edited collection, Marxism Against Postmodernism in Educational Theory (2002, Lexington Books) - which won an AESA Critics' Choice Award for 2004. Dr. Rikowski has researched on a number of topics, including: continuing vocational education (for HEFCE), further education college finance and curriculum (FEDA), and the UK horological industry (for The Worshipful Company of Clockmakers). His $\mathrm{PhD}$ was on the recruitment of engineering apprentices, awarded in 1989 from the University of Warwick. Glenn was a member of the Hillcole Group of Radical Left Educators from 1994-2002. With Anthony Green (UCL Institute of Education), Dr. Rikowski co-founded and ran the 'Marxism and Education: Renewing Dialogues' seminars twice-yearly (May and October) from 2002-2007. Also with Anthony Green, he co-founded the world's first book series on Marxism and Education: the Palgrave Macmillan Series on Marxism and Education, in 2004. He has

\footnotetext{
* Este trabajo corresponde al ciclo de entrevistas preparadas por el autor en el marco inaugural de la sección "Entrevistas a grandes personalidades de la Educación, las Ciencias Sociales y el Pensamiento Crítico" del Centro de Estudios Latinoamericanos de Educación Inclusiva (CELEI). Trabajo inédito.

** Chileno. Director del Centro de Estudios Latinoamericanos de Educación Inclusiva (CELEI). Académico del Programa de Magíster en Educación Inclusiva de la Univ. Santo Tomás, La Serena. Profesor de psicopedagogía en el Instituto Profesional Los Lagos, Rancagua. Doctor en Ciencias de la Educación aprobado sobresaliente por unanimidad, mención "Cum Laude” (UGR, España), con la tesis: "Epistemología de la Educación Inclusiva: un estudio sobre sus formas de construcción y fabricación del conocimiento”. Profesor de Educación Básica, Licenciado en Educación, Magíster en Educación, mención Currículo y Evaluación (UAC), Magíster en Educación, mención Política Educativa (ULARE), Máster en Lingüística Aplicada a la Enseñanza del Español como L2 (Univ. Jaén, España), Máster en Integración de Personas con Discapacidad (Univ. Salamanca, España), Post-titulado en Psicopedagogía e Inclusión, Pos-titulado en Pedagogía Universitaria con Orientación en Enseñanza para la Comprensión, Diplomado en Estudios de Género y Diplomado en Investigación Social del Cuerpo y las Emociones (U. Chile). Ha sido académico de importantes universidades chilenas, autor de numerosas publicaciones en el campo de la Educación Inclusiva. Permanentemente imparte conferencias en congresos internacionales gracias a sus escritos, así como, capacita universidades extranjeras y docentes e imparte seminarios en sus principales líneas de investigación a nivel nacional e internacional. Actualmente cursa el doctorado en Filosofía en la UGR, España, donde escribe su tesis doctoral sobre Historia Intelectual y Conceptual de la Educación Inclusiva. Contacto: aldo.ocampo.gonzalez@gmail.com - aldo.ocampo@gmail.com
} 
appeared on TV (BBC News 24) and on radio (BBC Radio 4), talking about aspects of education policy. Many of his publications can be found at Academia: http://independent.academia.edu/GlennRikowski Email: Rikowskigr@aol.com

La fotografía ha sido cedida por el entrevistado desde un archivo fotográfico personal para la publicación de esta entrevista.

\begin{abstract}
Aldo Ocampo González (AOG):
Thank you for engaging with the issues of Inclusive Education and Critical Pedagogy in this e-interview Glenn. I am curious and interested in what you have to say on these issues, especially in the light of your many years of writing on Marxism and education and Marxist educational theory.
\end{abstract}

\title{
Glenn Rikowski (GR):
}

I'm glad you mentioned that last bit Aldo! Many others would be more qualified than I to talk about Inclusive Education and Critical Pedagogy. But I would like to think that I have something different to say when these are connected with Marxist science. On that basis, I'm pleased to be doing this e-interview, and thanks for inviting me.

AOG: First of all Glenn, how would you define Critical Pedagogy for the $21^{\text {st }}$ century? What is your position today on this political and research program?

GR: This is a difficult question for me given how my life, career, political experiences and ideas have developed over the last 40 years. I will start by indicating how I would not answer this question. First, I would avoid delving back into the history of mainstream Critical Pedagogy in order to distill some essence, set of principles or foundations that can then be shot into the $21^{\text {st }}$ century. Neither would I recommend starting out from any particular Critical Pedagogy theorist or practitioner (such as Paulo Freire). This is because what I regard as mainstream Critical Pedagogy has become liberal in form rather than taking on an anticapitalist and post-capitalist trajectory. It is wise to remember why Peter McLaren and Paula Allman advocated a Revolutionary Critical Pedagogy as opposed to Critical Pedagogy, and a crucial aspect of the former was an engagement with Marx and contemporary Marxist thought. Others, such as Derek Ford and Curry Malott have also broadened out and ultimately gone beyond Critical Pedagogy in their engagement with Marxism and Marxist educational theory (Malott and Ford, 2015). Indeed, Derek Ford has taken Communist Study, rather than Critical Pedagogy as his starting point for thinking through an education allied to a communist horizon rather than what can be salvaged for education within capitalist society (Ford, 2016).

Secondly, my biography and intellectual development go against defining a Critical Pedagogy for the $21^{\text {st }}$ century based on a conventional starting point - which I would take to be the writings of Paulo Freire and the Critical Pedagogy School as developed principally in the United States, and then its dispersal throughout the Anglophone world. Although in the UK it is only in the last 15 years or so that Critical Pedagogy has gained a significant foothold in the academy. Rather, my intellectual development towards a radical educational outlook was forged through reading Marx and engaging with the Conference of Socialist Economists and its journal, Capital \& Class, in the 1980s and 1990s. Additionally, I had the good fortune to have studied for my $\mathrm{PhD}$ in the sociology department at the University of Warwick in the 
1980s, when people such as Simon Clarke, Tony Elger, Peter Fairbrother, Terry Lovell, Simon Frith and Bob Fryer were working there and developing Marxist theory in exciting directions. It was as a postgraduate student at the University of Warwick, from late 1979, that I took up the study of Karl Marx's writings in earnest and systematically. Therefore, my ideas on education were generated from reading Marx over many years, as opposed to starting out from Critical Pedagogy, or anywhere else.

Finally, it should be noted that my engagement with empirical work influenced my approach to generating radical ideas in education. Thus, I took what Marx and Engels said in The German Ideology seriously in terms of my own empirical work: 'Empirical observation must in each separate instance bring out empirically, and without any mystification and speculation, the connection of the social and political structure with production' (Marx and Engels, 1846, p.41). My $\mathrm{PhD}$ was on the recruitment of engineering apprentices, and involved interviewing employers, and also apprentices in a group training scheme. It was a big empirical study, interviewing apprentice recruiters in 107 firms and, strangely, the same number of apprentices, as well as collecting historical and contemporary data from trade union records, the careers service in the city I undertook the research in, and a local history centre run by the city council. Thus, to some extent, I built up by ideas on Marxist educational theory from this and other empirical studies (e.g. on working students, continuing vocational education and college finance).

Having given this biographical detail, perhaps my answer to your first question Aldo becomes more understandable. Therefore, I would not start out from Critical Pedagogy at all, and so attempting to define what 'Critical Pedagogy' would mean for the $21^{\text {st }}$ century would not be a main concern. Alternatively, my starting point would be Marx and a critique of capitalist education allied to practical adventures in forms of teaching and learning that attempt to develop education for post-capitalist futures.

Focusing on the first aspect, the central question for me is to pin down precisely what capitalist education is: what form, or forms education takes in capitalist society. These social forms of education in the social formation of capital are twofold, based on what Marx saw in Theories of Surplus V alue - Part One as the two great classes of commodity: labour-power and the general class of commodities (Marx, 1863, p.171). Analysis of these two commodity forms indicates what education in capitalist society is becoming: it allows us to grasp what Marx called the 'becoming of capital' (Marx, 1858) within educational institutions, processes and phenomena. The capitalisation of education is uncovered and exposed: education turning into capital through the two commodity forms, in terms of labour-power (becoming human capital') and the general class of commodities (through privatization, marketisation etc. of education). However, the critique of capitalist education through analysis of its commodity forms should not artificially separate education and its institutions and processes from the totality of capital's social formation. The critique of capitalist education must go hand-in-hand with the critique of capitalist society as a whole, and, in relation to education, the critique of capitalist work is essential for understanding education in contemporary society.

Only when the critique of capitalist education through analysis of its commodity forms has been developed up to a certain point is it possible to understand and critique adequately the various forms of inequality in capitalism; that is 'class inequality, sexism, racism, discrimination 
against gay and lesbian people, against disabled people, ageism and differential treatment of other groups', as I noted in my 'Marx and the Education of the Future' article (Rikowski, 2004, p.567). Of course, what is very common in Critical Pedagogy and radical education writing and research is to rush into the critique of various forms of inequality without bothering to relate these to commodity forms and the development of capital. The result of such impatience is to provide only policy proposals and strategies for ameliorating discriminatory processes and practices without getting to the root of these phenomena as aspects of the becoming of capital. Mainstream Critical Pedagogy typically evades and avoids Marxist analysis of contemporary education along the lines I have suggested.

In terms of what I have called practical adventures in education, these are sustained attempts to generate educational forms that are either antagonistic to capital in terms of its own development, the becoming of capital, or rest on the communist impulse. We can look to history for inspiration, such as the experiments in the USSR in the early years after the Russian revolution. Or we can explore alternative and free schools in the developed capitalist world. But what I find most exciting is work on generating co-operative forms of education that pose a challenge to conventional, capitalist and career- and money-centered education in contemporary capitalism. The work of Michael Neary, Joss Winn and others in the city of Lincoln at the Social Science Centre is an example of this development in England (see, for example, Neary and Winn, 2012; and Neary and Winn, 2017).

As well as creating alternative educational organisations to capitalist ones there is also the option of attempting to push existing schools, colleges and universities towards post-capitalism through struggling for democratic, open, co-operative and anti-capitalist education initiatives within them. A good example of this is the Student as Producer development at the University of Lincoln. The idea of 'student as producer' at Lincoln was inspired by Walter Benjamin's idea of the author as producer, but also by radical educators and theorists such as Vygotsky and Freire. The key feature of Student as Producer is to break down various dualities and antimonies: especially, teaching / research, and student / teacher. Students undertake research rather than passively studying the research of academic others. Student as Producer at the University of Lincoln 'should be understood as a large-scale project operating inside and across the university, grounded in social theory that is against what the university has become' (Winn, 2015, pp.50-51 - original emphases). Its pedagogic practices and theoretical underpinnings can be viewed as a program of 'immanent critique' of mainstream, capitalising university life (Winn, 2015; and for more on Student as Producer see Neary, 2010 and 2016). Of course, there are many examples of students pushing against the containment of education within capitalist forms, and the Chilean student movement in recent years has yielded such an example (see Simbuerger and Neary, 2015). Radical work experience programmes can challenge inequalities in capitalist work - rather than 'esteeming' work, or attempting to merely acclimatise students to it, and the work of the late Roger Simon is especially important here (e.g. Simon, 1983). In addition, educational processes that engage with human needs notwithstanding that 'needs' are sometimes manufactured in contemporary society - can have a radical edge. I write about this point, and also how students and teachers can, together, embark on educational processes that address their 'desires, wants and dreams' (Rikowski, 2004, pp.568-569). For all of these aspects critique must be foremost - even for seemingly positive initiatives and developments: this is necessary to drive beyond capital's educational 
forms. Critical Pedagogy, insofar as it posits a social universe beyond capital, should take up the sword of critique and in particular heave this weapon at capitalist education and capitalist work - taking in education policy and practice.

On the final part of your first question Aldo, in my view, and given what I have said above, there should be two interrelated research programmes for 'Critical Pedagogy' as I have framed it. These research programmes flow from the distinction Marx makes between the two great classes of commodities in Theories of Surplus Value - Volume One (Marx, 1863): labour-power and the general class of commodities. Taking the latter, general class first, the key issue for research is the capitalisation, the becoming of capital, in educational institutions, processes and phenomena. It follows from this starting point that the constituent processes and developments making for the capitalisation of education are therefore central to such a research programme: the privatisation, marketisation, commercialization and monetisation of education are particularly important here. I have written on these topics for the last fifteen years, including many blog pieces, reacting to education policy initiatives of the New Labour governments of Tony Blair and Gordon Brown especially. On the second research programme, that focuses on the capitalisation of labour-power, I have written and researched on this far longer; for the last thirty-five years. At the heart of this research programme are two features: first, the nature of labour-power in the capitalist social formation; and, secondly, its social production. Regarding the nature of labour-power in capitalism, I have argued that it takes a particular social form as buman capital, the human becoming capital. On the social production of labour-power in capitalism, which I have written about for at least twenty-five years, this is where the significance of education becomes more empirically apparent. What is happening, and has been for many years worldwide, is the reduction of education processes, practices and phenomena to labour-power production. Today this can be seen in the ideology of 'employability', in slogans such as 'work-ready graduates' and policies that place STEM subjects (science, technology, engineering and mathematics) to the forefront. In 2002, I wrote a paper outlining some preliminary methods for researching and analysing the social production of labour-power in capitalism (Rikowski, 2002).

Together, these two research programmes crystalise the nature of capitalist education, its constitution as capitalist social form(s).

AOG: What do you mean by a politics of 'buman resistance' to achieve progressive social change? This idea is mentioned in a number of your works. What are the implications of this concept for the transformation of education and to promote new anti-capitalist scenarios?

GR: These issues flow nicely from the end of my answer to the previous question. The politics of human resistance: this is something I wrote about with Peter McLaren, Dave Hill and Mike Cole in our Postmodernism in Educational Theory: Education and the Politics of Human Resistance edited collection (Hill, McLaren, Cole \& Rikowski, 1999), but this concept also played a part in our second extended edited book: Marxism Against Postmodernism in Educational Theory book of 2002 (Hill, McLaren, Cole \& Rikowski, 2002). First of all, I claim responsibility for the notion of 'human resistance' in both these books. It was my idea, and it figured in the sub-title to the 1999 book. However, after the 2002 book came out I began to see that a major weakness of both edited collections was that the concepts of 'human resistance' and 'politics of human resistance' had not been explored sufficiently. In 2006 I had a great opportunity to remedy this 
situation. I was invited by the editorial board of Information for Social Change to edit a special issue of the journal on 'Education for Social Change'. My main contribution to the special issue was an article on 'Education and the Politics of Human Resistance' (Rikowski, 2006a). Therefore, much of what I have to say here comes from that article, but I have also seen problems with a 'politics of human resistance' in recent years, which I will articulate here. Furthermore, part of the answer to the previous question referred to the 'politics of human resistance' so I will try to avoid too much repetition.

In general, the politics of human resistance refers to resistance to the encroachments of capital in all areas of contemporary social life. To resist the extension, intensification and augmentation of capital on human existence - and this includes capital's depredations on the natural environment and outer space. What we have to resist specifically in education is its reduction to labour-power production. This reduction hollows out educational processes and practices of radical content whilst bolstering the vigour and vitality of capital in society and pathologises labour and its human representatives. It is ironic that some radical educational theorists and researchers claim that some Marxist educational theory is 'reductionist', such as Kenneth Saltman (see 2010, pp.119-124, and in Schooling in Capitalist America blog, 2011), and Michael Apple (2006), when the reduction of education to labour-power production gathers pace and intensity in capitalism today. But the processes involved in the social production of labour-power incorporate a deeper threat to the form of the human in capitalist society. This is the project of capital and its human representatives to convert labour-power into buman capital, the human in the form of capital. Capital is antagonistic to resistance, barriers to its development. The fact that labourers control the only commodity that can expand value and hence surplus-value - i.e. labour-power - this is a real challenge to capital. Thus, there is a project to convert labour-power into human capital, the social form that labourpower takes in capitalist society; the human as capital. Human capital is a horrific concept, and a conception that manifests horror! The formation of labour-power as human capital involves human beings incorporating the contradictions of capital (e.g. between value and use-value) into their psyches. This results in mental stress and sickness as labourers attempt to meet capital's contradictory demands in the capitalist labour process. If workers cannot rise to the occasion then they are pathologised, with anti-depressant drugs, psychoanalysis, counselling, managerial victimisation, bullying and pressure moving into the situation. Fortunately, in our capitalist social formation, humans are constituted as and by labour, as well as by capital. Collectively, therefore, the organisations of labourers in capitalist society (e.g. trade unions) can struggle against the tendency to fracture and reconstitute human labour-power, and thereby humans (as labour-power is incorporated within the human), as human capital. There is a constant struggle between the representatives of capital and labour regarding the form of the human in contemporary society, and education is a key battlefield in this struggle.

As I said in the Education and the Politics of Human Resistance, as far as education is concerned: 'The politics of human resistance does not really exist in any explicit form today. At its heart is opposition (human resistance) to the reduction of education and training to -labour-power production' (Rikowski, 2006a, p.12). The politics of human resistance involves 'a relentless focus on this form of resistance as the most significant anti-capitalist strategy' (Ibid.). This is because 'it drives at capital's weakest link: labour power' (Ibid.). 
The main problem with a 'politics of human resistance' is that it is reactionary. Resistance is a defensive concept and response: stopping something happening that capital and its human representatives initiate, a pay cut here, a redundancy programme there, or benefits cuts or education budget slashed, or a school being run for profit. In that sense, it is a concept bound to the capitalist formation: capital intensifies, extends and subsumes; labour resists these tendencies, policies, regressive changes. Yet labour needs not just to be more assertive, but also to attack the social relations of production in capital's social universe through organising social forms that challenge the rule of capital in social life. That is the significance of the cooperative, open and alternative forms of education I referred to earlier.

AOG: What is the relevance of Marxism today for igniting radical social change in the areas of social justice and Inclusive Education?

First of all Aldo, I would take issue with how the question is framed. It seems to suggest that Marxism itself can ignite radical social change for social justice and Inclusive Education. The reading and writing of Marxism and Marxist theories and texts and Marxist research, by themselves, probably do not ignite radical social change for social justice and Inclusive Education. Of course it could be argued that Marxism had a role in igniting radical social change in Russia in 1917 and for a few years after the revolution, though whether the workers, peasants and soldiers were inspired directly by the works of Karl Marx in making their revolution is open to question. Apparently, it was Friedrich Nietzsche that was read by Russian soldiers in the trenches in the First World War, more than Marx. But your question is for today, contemporary society, Aldo, and I can only speak for the UK, the society where I live, and I know to some extent. In this context, and for this time, it is unlikely that Marxism has much relevance for igniting radical social change. There has not been much radical social change in any area of social life in the UK for several decades. Instead, regressive, retrocapitalistic social change has been the norm, backed by governments - both Conservative and Labour - geared up to delivering the neoliberal agenda. Of course, there have been a few instances of progressive reform, such as the Sure Start programme for early learning and tax credits for the working poor brought in by the New Labour governments, and now under attack from the Conservative government. There have also been outbreaks of indignation in the liberal Left media over issues of social inclusion within education, such as the failure of elite universities such as Oxford and Cambridge (known together as 'Oxbridge') to recruit black and ethnic minority students and poor white students. Thus, based on 2016 intake data, Richard Adams in The Guardian showed that Oxford University needed to overhaul its admissions programme as the data indicated there was a clear "unconscious bias" against black and disadvantaged applicants (Adams, 2017a, p.1). The 2015 admissions data for Oxford University showed that its constituent colleges admitted no black students (Adams and Bengtsson, 2017, p.1) and David Lammy, a former Labour education minister and current Member of Parliament accused the Oxford of "social apartheid", and one of Oxford's colleges, Oriel, had only admitted one black British student in six years (Ibid.). More recently, David Lammy, using data that came from a freedom of information request to all Oxbridge colleges, showed that their intakes were 'wholly unrepresentative of the country at large' and 'the overwhelming majority of their students [came] from a small, privileged minority in the south of England' (Lammy, 2017, p.1). Marxist science can work well to explain this situation and advance a corresponding argument for greater fairness in admissions practices at Oxbridge, 
and Mike Cole's analyses of racism in education in the UK and the US, coming from a Marxist perspective provide important insights.

However, your question was about Marxism igniting radical social change rather than explaining it, and on this score Aldo, the forces of Marxism, in the UK at least, are too weak to generate radical change on a significant scale. In my lifetime, I would say that, as a political force, Left parties advocating Marxism have never been weaker.

On the other hand, there is cause for hope on a number of fronts. First, bubbling underneath the decline in far Left parties with a Marxist badge, there have been significant advances in Marxist theory, too many to list here. In addition, the infrastructure for Marxist theory, debate and analysis has strengthened, with conferences such as the Historical Materialism London Conference and many day conferences making important contributions. Another aspect of this infrastructure is the development of new Marxist journals in the last twenty years such as Historical Materialism, and the rise in quality and quantity of Marx-inspired books. This can be seen in the field of education, with the Journal for Critical Education Policy Studies established by Dave Hill making significant contributions to Marxist educational theory. In Canada, the Critical Education journal is having a similar effect. In 2004, Tony Green and I set up the world's first Marxism and Education book series with Palgrave Macmillan, and Routledge went on to establish another such book series. From anecdotal evidence, Marxist readings groups seem to be flourishing. Secondly, the 2007-09 Great Recession and subsequent Great Depression have changed the intellectual climate somewhat. Marx at least gets more of a sympathetic role in the mainstream liberal media, for example. Thirdly, in the UK there is the Corbyn phenomenon. Never in my lifetime did I expect to see a shadow chancellor in the Labour Party openly advocating Marxist theory. Such is John McDonnell. Some years ago, I spoke with him on an openly Marxist platform. Finally, some yearn for a Left Brexit that brings Marxist theory more to the fore in policy formation and the struggle for social justice. Personally, I see Brexit as a gift to the Radical Right, and, in the wider country, to antiimmigrant and racist forces and Little England imperial fantasists: we are not Brexiting on a Left, progressive ticket dedicated to enhancing social justice in British society. I hope I am wrong, and perhaps a Corbyn-led Labour government can reverse the current Right Brexit trajectory.

Having said all this, we should not get carried away. Any radical social change is unlikely in the current climate, especially in education. With the various crises in schools in the UK, over teacher shortages, budgetary constraints (with inadequate capital expenditure), a longstanding lack of emphasis on race, gender and class issues in teacher training, the drive to turn schools into businesses, and much more, then projects for creating more social justice and Inclusive Education in schools do not look promising. Of course, heroic individual teachers, in particular schools sometimes buck the trend, but against great odds.

AOG: Why do you claim that Marxism is not primarily a theory of society, but a theory against society that begins to open perspectives of education as an anti-capitalist activity?

The idea that Marxism is a theory against society is not mine originally. The notion comes from the work of John Holloway. I have read Holloway's work for many years, since the late 1970s, with his work on the capitalist state, undertaken with Sol Picciotto (who was also at the University of Warwick when I was doing my PhD research). For Holloway, and for me, 
Marxism is not just a theory that explains what is going on in society; mainstream sociology will do that for you, although Marxism does this even better. Neither is Marxism just a theory of oppression or domination; there are many other theories of oppression, such as feminism, Green theory and anti-racist theories. For Holloway, Marxism is not just about understanding oppression. Thus, in radical educational theory and research, and in mainstream sociology of education, there is the perennial question of why working-class children do not do as well as middle-class children in terms of educational outcomes, university entrance and labour market success. Depressing study after depressing study confirms and re-confirms the gap between these Weberian strata (for working / middle class is a division within the mass of labourers) in terms of educational results, in terms of tests, on examinations and other measures of outcome. This can be viewed as a form of oppression, where the cards are stacked against the children of relatively disadvantaged labourers. Capitalist education becomes all the more oppressive as it viruses state-financed public education and operates more fully as capital, with the development of privatisation, for-profit education, education markets selling a multitude of education commodities, the intensification of education as labour-power production, and so on. The institution and raising to rip-off levels of higher education fees in England is an example of the level of oppression being ramped up, with some terrible consequences for students and higher education teachers, as well as great opportunities for university leaders to squeeze out ever higher salaries from the system (see for example, Adams, 2017b).

Marxism does not just seek to explain oppression but starts out from the fact that we live in an oppressive society and attempts to understand the fragility of capital's existence and development. Marxism focuses on the weaknesses of capital, starting out from its dependency on labour and the labour-power of labourers in capitalist society. Furthermore, argues Holloway (1994), Marxism is also a theory that articulates the contradictions of capitalist oppression and so 'This gives Marxism a special relevance for any person or movement interested in a radical transformation of society' (1994, p.40). It is by analysing the contradictions of capitalist oppression that weak points in capital's mode of existence and functioning can be located. For me, this is the real point of Marxism, and if a better theory was generated to this end then I would forsake Marxism. These contradictions and weaknesses in the rule of capital can become points of focus, critique and political action. As I noted in 2006: 'In its project of pinpointing fragilities in capitalist oppression Marxism facilities the formation of political strategies of maximum effect' (Rikowski, 2006a, p.3).

Marxism is also a theory of crisis, of capital's crises. Such crises also lay bare certain weaknesses of capital's mode of existence of capital. Thus: fragility, weakness, contradiction, crisis, allied to the 'ruthless criticism of all that exists' (Marx, 1843 - original emphasis), are required for a thoroughgoing critique of capitalist social forms and relations, including capitalist education. All this is advanced on a foundation of negativity, for as we scream 'No!' to capital it becomes clear that: 'We are the only reality, the only power. There is nothing but us, nothing but our negativity' (Holloway, 1995, p.159). We are the crisis of capital and proud of it (Holloway, 2016).

AOG: What political limitations does Marxism express today in relation to ensuring progressive social and educational change? 
I have partly answered this already, I think Aldo. Marxist-inspired political parties are especially weak in the UK today, as I noted earlier, and I don't know whether this is true in Chile or elsewhere in Latin Americas. I have never travelled outside Europe. I would tend to reframe the question: why is Marxism of limited consequence in politics today? But even this question has its own limitations. First, the late Paula Allman expressed to me in conversation many times, and in her work (especially Allman, 2007), that it is a mode of bourgeois thought to separate out the 'political' from the 'economic' in our thinking, or the 'educational' sphere, come to that. She argued that: 'Marx would have scorned the idea of a Marxist educational theory because it implies that education belongs to some separate aspect of human life rather than being an integral part of the process of 'becoming', i.e., the lifelong process of developing all of our human potential and powers' (Allman, 2007, p.51). To understand life in capitalist society argued Allman, it does not make sense to view its existence as the 'sum of many separate and distinct parts rather than as a totality of inner-connected relations' (p.52). Even empirically, the social production of labour-power is carried out in the first instance in educational institutions, but it also takes place in training organisations and processes, a range of workplace learning initiatives and in the capitalist labour process itself. Thus, as far as the social production of labour-power is concerned, the separation between 'education' and 'economy' does not make sense. Sociological structuralism, even of a 'Marxist' kind, mystifies the real processes that are going on.

Taking these points into account, I would still use the idea of 'Marxist educational theory' to denote the contributions of Marxist thought and research to understanding and critiquing educational processes, practices and institutions in capitalist society. The 'political limitations' of Marxism as a project for progressive social change are an expression of its underdevelopment. These limitations rest on the fact that much more works need to be undertaken that focuses on the elements indicated above: capital's fragility, its weaknesses, its crises, its contradictions. Specifically, regarding what goes on in schools, colleges and universities, Marxism has only gathered depth and quality of analysis since the early 1970s. Bowles and Gintis (1976) and Willis (1977) boosted considerably the vitality and visibility of Marxist theory and research in education. The 1980s and early 1990s were a bad time for Marxism in the field of education, with young radical and critical educators being lured by the false promises of postmodernism, with the 'death of Marxism' syndrome hanging over their heads post-1989. Yet Marxist theory and writing on education recovered from the mid-1990s, and the development of younger generations of Marxist theorists and researchers in the last 20 years or so bodes well for the future, and, as I noted earlier, there is more of an infrastructure supporting them than there was before the millennium.

Of course, there many non-Marxist theorists, and even some claiming to be sympathetic to Marxism, that heap a pile of limiting and debilitating accusations on Marxist research and theory in education: that it is reductionist (though they rarely say what this means), determinist, functionalist, places too much emphasis on class at the expense of gender, race and other forms of social injustice and inequality, does not address the historical failures of actually existing socialist societies (which they take to be based on vulgar Marxism), and so on. I have replied to some of these criticisms, which, if valid would place severe moral, political and theoretical limitations on Marxism (see Rikowski, 2006b). But I will not waste any more text on them here. 


\section{AOG: What relationship could exist between Critical Pedagogy and Inclusive Education?}

GR: Presumably a number of relationships could exist between Critical Pedagogy and Inclusive Education. I have already vented scepticism towards the value of Critical Pedagogy as currently constituted, its mainstream version, yet so far I have said little about Inclusive Education. My starting point would be that none of us are excluded from capitalist society as a whole; that is impossible. As Christian Lotz (2014) makes clear, what he calls the "capitalist schema" which is not just in our consciousness (it is not merely ideology), but is also inscribed in the constituted social world based on capital, has no room for exclusion; all is gathered into its orbit, and the money form of capital plays a crucial role here. However, we are included differentially; capitalism is a vast inequality and inequalities generating machine! The next step is to explore how individuals and groups are excluded (absolutely or relatively) from institutions and organisations and from Weberian life-chances. What flows from this is that the concept of Inclusive Education (or inclusion in general) is a thoroughly capitalist notion. When social groups, on which the idea of social justice is based, forge a collective identity in search of a better life in contemporary society, then this occurs on the basis of struggle within the capitalist social formation. In the context of capitalist society, I would concur with Paula Allman that social justice within capitalism is impossible.

There are alternatives. One alternative is that, even if social justice in capitalism is impossible, it can be defined as the struggle for social justice in capitalism; this struggle for impossibility attains its own reality in active attempts at resolution. Social justice is the struggle for social justice, and therefore relative social inclusion is advanced on the basis of these struggles. Inclusive Education can be viewed as a struggle for social justice that attains a mode of existence of social justice itself, but without attaining social validity. Thus, active struggles for Inclusive Education as forms of social justice development can also be viewed as lacking social validity. They tragically lack this validity as there is no just wage, just profit, just level of surplus-value extraction, just education system and so on, in capitalist society. However, this will not stop or inhibit social groups advancing their interests vis-à-vis other groups in education, or in any other set of institutions. Struggles for social justice and Inclusive Education are as old as capitalism and will continue to its grave.

The other alternative is to search for forms of social justice that have social validity. This is a harsh option, which indicates the terror of capital as a social force. It is based on the notion that different groups of people and different individuals have labour-powers of varying values. On this account, labourers whose labour-powers are lowers than others have correspondingly less value as persons. Thus, on this basis, on the foundation of capital, it is socially valid that men have higher pay than women on average; they have, on average, higher quality labourpowers. This abominable way of thinking as capital, ourselves as expressing capital within us, has real social consequences, which liberal Left academics are loath to acknowledge. They avoid making the connections. For example, the UK Chancellor of the Exchequer, Philip Hammond, recently argued that the reason the UK had poor productivity levels was that it employed more disabled people than other countries. Basically, people with disabilities are not as productive workers as able bodied workers (De Cordova, 2017). Hence, on average they produce less value and therefore generate less profit. In effect, they have labour-power of less value than the average worker, so that socially, in capitalist society, they are worth less as persons carrying inferior labour-powers, and should be paid less, or preferably not be 
employed at all; and then the socially average quality of labour-power would rise and ceteris paribus, socially necessary labour-time would decrease and value-producing labour-time would increase, as would surplus-value production. Thus, it is not strictly true that social justice is impossible in capitalist society, as noted earlier. Social justice is possible on the foundation of capital. This mode of thought grasps a form of social justice in capitalist society that has social validity based on the functioning and development of the capitalist social formation, but which, to most people, is an abomination, and from the perspective of labour does not represent social justice at all, and must therefore be rejected!

AOG: Has the rationality of capitalism conditioned the field of struggle on Inclusive Education? How is this expressed in the educational agendas?

First of all Aldo, I would not accept that capitalism has a 'rationality' when it is riven with contradictions, tensions and weaknesses. That it develops, extends and intensifies is clear, but it does this on the basis of these contradictions etc., and also partly as a result of opposition and antagonism from us: from labourers, individually, but most importantly collectively. We are the crisis, as John Holloway (2016) has it. We disrupt, subvert, and endanger capital at times, as we struggle for a better life within its social universe. Nevertheless, as Bowles and Gintis (1976) in the US context showed all those years ago, schooling and public education in general grade, test, sort and credentialise students in order to facilitate labour market inequalities based on hypothecated labour process performance.

I saw this at work in my own PhD research on the recruitment of engineering apprentices. The recruitment process is the great sorting house for capital; young people were judged on the basis of various criteria of recruitment that hinged on their projected performance in engineering labour processes after (and in some cases during) a period of training in various engineering trades. At one level it was a 'rational' process; the engineering companies were trying to get the 'best' (however they defined it) young people they could get. But I came across much evidence that factors such as race and gender figured in their calculations, with a strong emphasis on these young people 'fitting in' with the culture, ethnicity and gender of the existing workforce, as it was believed by many that such discrimination would facilitate workplace solidarity and cohesiveness. In the 1990s, I explored studies which concluded that a racially homogenous workforce would, everything else being equal, be more productive. If valid, such studies therefore lent a racist rationality to discriminatory recruitment practices! Thus, the optimal functioning of capitalist enterprises engendered racist recruitment practices on the basis of these studies. Yet I came across other studies that argued that such recruitment strategies were irrational as employers using them were more likely have a lower quality workforce than average as they were ignoring more potentially productive ethnic minority workers over less productive and useful white workers.

The point here is that, at the empirical level, capital (personified in its human representatives) has many 'rationalities', which come into conflict, as they reflect deeper phenomena. This is in addition to capital's overarching rationality of expansion and intensification - which is subject to contradiction and crises. Any Inclusive Education drawing on Critical Pedagogy (or any pedagogy) has to negotiate and live with these tensions this side of a post-capitalist world. 
AOG: Therefore, from what you have said how should we think about Inclusive Education and its praxis, based on the nature of capitalist society in which we find ourselves? In addition, how should we view educational policies on the subject?

GR: Based on what I said previously, in response to a number of your questions Aldo, then those struggling for Inclusive Education in contemporary society must realise that this struggle is interminable as long as capitalism exists. Social justice in capitalism is impossible as there are no criteria which socially validate any particular configuration of societal positions for groups, in general, or in relation to education, that are acceptable in terms of equality and respect for persons. It is possible to assert a conception of social justice based on capital itself, in relation to the values of various labour-powers and their social averages for groups; but this degenerates into abominable conclusions that run counter to acceptable ideas of social justice from the perspective of labour. Furthermore, given the development of capitalism, new sources of differentiation and inequality will occur; for example, in information technology use in the last 30 years.

All that can be done is to continue to struggle for social justice and Inclusive Education on the basis that the struggles for social justice and Inclusive Education in capitalist society constitute the extent to which these attain real existence in capitalism. Thus: social justice is the struggle for social justice; Inclusive Education is the struggle for Inclusive Education. These struggles are set in capital, and may turn out to be against capital when pushed far enough. Organisations of education and training that are based on co-operative principles, a form of solidarity based on workers' control and democracy (as opposed to forms of solidarity and co-operation based on capital), can begin to go beyond capital as transitional forms. To the extent that this occurs, Inclusive Education can take on identity as itself.

Answering the second part of the question, of course government measures aimed at enhancing Inclusive Education should be supported, but with severe reservations and scepticism. For example, educating young people with various forms of disability in mainstream schools appears to be a worthy policy. But even on this issue I will never forget a student of mine that did a dissertation arguing the opposite: that for people like him, dedicated schools, with expert teachers trained to teach youth with specific disabilities are preferable to an education in a mainstream school! The obvious solution is to have more expert teachers in mainstream schools. Yet my student argued that it was also a question of not receiving enough respect from other students and teachers, and as he went to both a school dedicated to dealing with special educational needs and a mainstream school, and as his experience was a relatively unhappy one in the latter, then he felt he had a point. Again, this becomes another challenge for Inclusive Education and the training of teachers and education of students. Failing these initiatives, then the position that inclusion should not be forced becomes an option; that those concerned regarding the inclusionary policies should be given a choice over the matter.

However, it should always be remembered that the state churning out these policies is a capitalist state. The capitalist state not only frames policies that enhance the capabilities and wellbeing of capital in general and national capitals, and sectoral and individual capitals in particular, but can itself be viewed as a form of capital. Thus, some policies that appear to be progressive, such as educating all children together, including those with mental and physical disabilities, may be carried out as cost-cutting measures, but marketed as 'progressive' social 
initiatives. The policies need to be scrutinized very carefully; on their intentions, the extent to which the recipients have real choice in the matter, and their effects on well-being, human progress and capability.

AOG: What do you think are the critical difficulties expressed by the pedagogical and research program of Critical Pedagogy in the $21^{\text {st }}$ century?

GR: Manifold! Varied! Multiple! There will be so much more to be critical about in the $21^{\text {st }}$ century! The strengthening of nationalism, especially here in Europe, the threat of nuclear war, climate change and environmental devastation, mainstream politicians hooked into neoliberalism, incipient Fascism (e.g. Austria, Hungary), growing divides between rich and poor (people and nations), and much, much more!

On top of this, teachers wishing to practice any kind of critical pedagogy in public, statefinanced schools, be it a mainstream Critical Pedagogy flowing from Paulo Freire, revolutionary critical pedagogy (after Peter McLaren) or the kind of critical education starting out from Marx (as opposed to Freire) that I have advocated, will face ever greater discipline, containment, surveillance and the imposition of business values and practices.

Underlying this is the breakdown of civilisation based on capital. The central contradiction in the development of capital - the project of expelling labour-power from the capitalist labour process through technological innovation, whilst the activity of labour in production is the source of value, surplus-value and profit - is ripening as machines and information technology expel labour as a productive force on an ever greater scale. The drive for productivity nurtures the tendency of the rate of profit to fall. For us, the contradiction between the ability to generate abundance based on the application of technology and science, and the poverty of life based on the value-form of labour and the iron cage of capital in its money form will become intense. Huge piles of debt, personal and sovereign, are one result. Massive inequalities of wealth, income and power are another.

Thus, at a time when all forms of Critical Pedagogy are required more than ever, state resources and state inclinations to allow it to exist and flourish are tragically constrained. In these circumstances, and given the intellectual freedom opened up, alternative and cooperative educational forms become not just essential but become more viable, and certainly more joyful!

AOG: Finally Glenn, what ideas would allow us to think about the relationship between democracy and inclusion? What ideas of Freire could be considered key in this understanding?

GR: As noted previously, I would not start out from Freire, but from Marx, so I will leave the second part of the question alone. Regarding rethinking democracy and inclusion, my starting point would be the important chapter XIII of Marx's Capital on 'Co-operation' (Marx, 1867, pp.305-317). Allied to the collective aspect of labour-power, the moment of co-ordination of labour-powers in capitalism, the rethinking of co-operation as a form that is not despotic (Marx, 1867, p.31) is crucial, where democracy takes the form of a workers' democracy that breaks down divisions of manual / mental labour, academic / non-academic, student / teacher and a host of other dualities. 
Added to this, in terms of discovery and its application to human progress, I would advocate the idea of 'study' (after Derek Ford, 2016), and also 'joyful expression' in its individual and collective forms, as opposed to the dead hand of capitalist learning and education. We learn with joy, for ourselves and with others! Only when, and to the extent, that negativity and a pedagogy of hate (for the time of capital and its machinations and workings in education and the whole of social life) (Neary, 2017) are no longer necessary for vanquishing capital and all that it brings, can joyful expression find its full voice and reality.

\section{References}

Adams, R. (2017a) Oxford University accused of failing to deal with admissions racism, The Guardian, 14 th January, online at: https://www.theguardian.com/commentisfree/2017/oct/20/oxfordcambridge-not-changed-diversity-even-worse-admissions [Accessed 16 January 2017].

Adams, R. (2017b) University students failed by rip-off fees, says watchdog, The Guardian, $8^{\text {th }}$ December, online at: https://www.theguardian.com/education/2017/dec/08/university-studentsfailed-by-rip-off-fees-says-watchdog [Accessed 9 December 2017].

Adams, R \& Bengtsson, H. (2017) Oxford accused of 'social apartheid' as colleges admit no black students, The Guardian, 19 ${ }^{\text {th }}$ October, online at:

https://www.theguardian.com/education/2017/jan/14/oxford-university-accused-of-failing-to-dealwith-admissions-racism-david-lammy

Allman, P. (2007) On Marx: An Introduction to the Revolutionary Intellect of Karl Marx, Rotterdam: Sense Publishers.

Bowles, S. \& Gintis, H. (1976) Schooling in Capitalist America: Educational Reform and the contradictions of Economic Life, London: Routledge \& Kegan Paul.

De Cordova, M. (2017) Philip Hammond is making the disabled a scapegoat for the Tory failure on productivity, New Statesman, December, online at:

https://www.newstatesman.com/politics/economy/2017/12/philip-hammond-making-disabledscapegoat-tory-failure-productivity

Ford, D. (2016) Communist Study: Education for the Commons, Lanham MD: Lexington Books.

Hill, D., McLaren, P., Cole, M. \& Rikowski, G. (eds.) (1999) Postmodernism in Educational Theory: Education and the Politics of Human Resistance, London: The Tufnell Press.

Hill, D., McLaren, P., Cole, M. \& Rikowski, G. (eds.) (2002) Marxism Against Postmodernism in Educational Theory, Lanham MD: Lexington Books.

Holloway, J. (1994) The Relevance of Marxism Today, Common Sense: Journal of Edinburgh Conference of Socialist Economists, No.15 (April), pp.38-52.

Holloway, J. (1995) From Scream of Refusal to Scream of Power: The Centrality of Work, in: W. Bonefeld, R. Gunn, J. Holloway \& K. Psychopedis (eds.) Open Marxism 3: Emancipating Marx, London: Pluto Press.

Holloway, J. (2016) In, Against, and Beyond Capitalism: The San Francisco Lectures, Oakland CA: Kairos. 
Lammy, D. (2017) Seven years have changed nothing at Oxbridge. In fact, diversity is even worse, The Guardian, 20th October, online at: https://www.theguardian.com/commentisfree/2017/oct/20/oxfordcambridge-not-changed-diversity-even-worse-admissions

Lotz, C. (2014) The Capitalist Schema: Time, Money, and the Culture of Abstraction, Lanham MD: Lexington Books.

Marx, K. (1843) Letter to Arnold Ruge, Letters from the Deutsch-Französische Jahrbücher, Krueznach, September 1843, online at: https://www.marxists.org/archive/marx/works/1843/letters/43_09.htm

Marx, K. (1863) [1975] Theories of Surplus Value - Part One, London: Lawrence \& Wishart.

Marx, K. (1858) [1973] Grundrisse: Foundations of the Critique of Political Economy (Rough Draft), Harmondsworth: Penguin Books.

Marx, K. (1867) [1977] Capital: A Critique of Political Economy - Volume 1, London: Lawrence \& Wishart.

Marx, K. \& Engels, F. (1847) [1976] The German Ideology, Moscow: Progress Publishers.

Malott, C. \& Ford, D. (2015) Marx, Capital, and Education: Towards a Critical Pedagogy of Becoming, Peter Lang: New York.

Neary, M. (2010) Student as Producer: A Pedagogy for the Avant-Garde: or, how do revolutionary teachers teach? Learning Exchange, Vol.1 No.1, available online at: http://josswinn.org/2014/04/05/student-as-producer-3/ [Accessed 12 December 2017].

Neary, M. (2016) Student as Producer: The Struggle for the Idea of the University, Other Education: The Journal of Educational Alternatives, Vol.5 Issue 1, pp.89-94.

Neary, M. (2017) Pedagogy of Hate, Policy Futures in Education.Vol.15 No.5, pp.555-563.

Neary, M. \& Winn, J. (2012) Open education: Common(s), communism and the new common wealth, ephemera: theory \& politics in organization, Vol.12 No.4, pp.406-422.

Neary, M. \& Winn, J. (2017) Beyond Public and Private: A Framework for Co-operative Higher Education, Open Library of Humanities, Vol.3 No.2, DOI: http://doi.org/10,16995/olh.195

Rikowski, G. (2002) Methods for Researching the Social Production of Labour Power in Capitalism, a paper for the University College Northampton, School of Education, Research Seminar, 7th March 2002.

Rikowski, G. (2004) Marx and the Education of the Future, Policy Futures in Education, Vol.2 Nos. 3 \& 4, pp. 565-577.

Rikowski, G. (2006a) Education and the Politics of Human Resistance, Information for Social Change, Issue No.23, (summer), at:

https://www.academia.edu/5997035/Education_and_the_Politics_of_Human_Resistance [Accessed 7 December 2017].

Rikowski, G. (2006b) In Retro Glide, Journal for Critical Education Policy Studies, Vol.4 No.2 (November): online at: http://www.jceps.com/?pageID=article\&articleID=81 [Accessed 27 November 2017].

Saltman, K. (2010) The Gift of Education: Public Education and Venture Philanthropy, New York: Palgrave Macmillan.

Schooling for Capitalist America (2011) The Pioneers of Marxist Thought in Education: A Review of Marx and Education by Jean Anyon, Part One, Schooling in Capitalist America: A Socialist Perspective on the Politics of Education, (Wordpress blog, Comments section), May 24 ${ }^{\text {th }}$, online at: 
https://schoolingincapitalistamerica.wordpress.com/2011/05/24/the-pioneers-of-marxist-thought-ineducation-a-review-of-marx-and-education-by-jean-anyon-part-one/ [Accessed 4 December 2017].

Simbuerger, E. \& Neary, M. (2015) Free Education! A "Live" Report on the Chilean Student Movement 2011-2014 - reform or revolution? [A Political Sociology for Action], Journal for Critical Education Policy Studies, Vol.13 No.2, pp.150-196.

Simon, R. (1983) But Who Will Let You Do It? Counter-hegemonic Possibilities for Work Experience, Journal of Education, Vol.165 (summer) pp.235-256.

Willis, P. (1977) Learning to Labour: How Working Class Kids Get Working Class Jobs, Farnborough: Saxon House.

Winn, J. (2015) The co-operative university: Labour, property and pedagogy, Power \& Education, Vol.7 No.1, pp.39-55. 